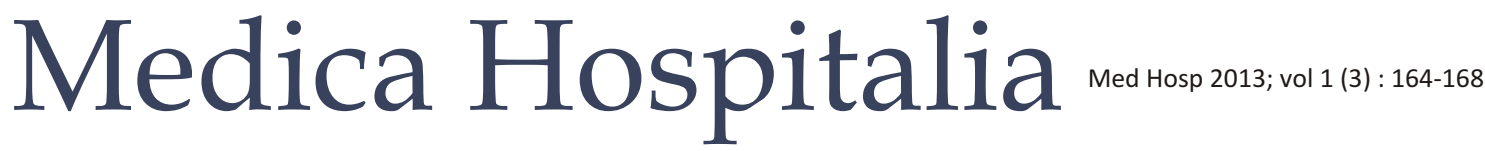

Original Article

\section{Karakteristik Pasien HIV/AIDS dengan Kandidiasis Orofaringeal di RSUP Dr. Kariadi Semarang}

\author{
Muchlis Achsan Udji Sofro*, Innes Angita**, Bambang Isbandrio*** \\ *Bagian/SMF IImu Penyakit Dalam, ***Bagian/SMF Mikrobiologi Klinik, \\ **Mahasiswa Fakultas Kedokteran Universitas Diponegoro/RSUP Dr. Kariadi Semarang
}

\begin{abstract}
Abstrak
Latar belakang : Epidemi HIV/AIDS di Indonesia merupakan salah satu yang paling cepat di Asia. Penelitian di RSUP Dr. Kariadi Semarang menunjukkan bahwa infeksi oportunistik yang tersering pada pasien HIV/AIDS adalah kandidiasis orofaringeal sebesar 79\%. Kandidiasis orofaringeal merupakan infeksi oportunistik mukosa yang banyak disebabkan oleh jamur Candida albicans, tetapi dapat disebabkan oleh spesies lain seperti Candida glabrata, Candida tropicalis dan Candida krusei. Tujuan penelitian adalah mengetahui karakteristik dan jenis kandida pasien HIV/AIDS dengan kandidiasis orofaringeal di RSUP Dr. Kariadi Semarang.

Metode : Penelitian deskriptif observasional pada pasien HIV/AIDS dengan kandidiasis orofaringeal yang dirawat di Bangsal Penyakit Dalam RSUP Dr. Kariadi Semarang pada Desember 2010-Mei 2011. Kriteria diagnosis melalui identifikasi mikrobiologi (pengecatan gram, kultur, germ tube dan fermentasi) Hasil : Total 42 Pasien HIV/AIDS dengan kandidiasis orofaringeal terdapat 29 laki-laki (69\%), rentang usia terbanyak 30-39 tahun, pekerjaan buruh dan pegawai swasta $(21,43 \%)$, pasien sudah menikah (88,09\%), underweight $(52,38 \%)$, berasal dari Semarang $(33,33 \%), C D 4<50 \mathrm{sel} / \mu \mathrm{l}(78,57 \%)$. Hasil kultur mikrobiologi 40 sampel tumbuh koloni kandida, $75 \%$ tumbuh $>300$ koloni kandida, jenis spesies kandida $55 \%$ non C. albicans yang terdiri dari C. stellatoidea $15 \%$, C. tropicalis $15 \%$, C. parapsilosis $12,5 \%$, C. krusei 7,5\%, C. glabrata 2,5\%, C. guilliermondia 2,5\%.

Simpulan : Pasien HIV/AIDS yang menderita kandidiasis orofaringeal sebagian besar mempunyai CD4 $<50 \mathrm{sel} / \mu \mathrm{l}$, didapatkan koloni kandida pada kultur mikrobiologi dengan $55 \%$ diantaranya jenis non C. albicans.
\end{abstract}

Kata kunci : Kandidiasis orofaringeal, HIV/AIDS

\section{Characteristics of HIV/AIDS patients with oropharyngeal candidiasis in RSUP Dr. Kariadi Semarang}

\begin{abstract}
Background : HIV/AIDS epidemic in Indonesia is one of the fastest growing epidemic in Asia. A study in RSUP Dr. Kariadi Semarang showed that the most common opportunistic infection on HIV/AIDS patients was oropharyngeal candidiasis, which was $79 \%$. Oropharyngeal candidiasis is a mucosal opportunistic infection moslty attributed to Candida albicans, but can also be caused by any other species, i.e Candida glabrata, Candida tropicalis, and Candida krusei. The aim of the study was to describe the characteristics of HIV/AIDS patients with oropharyngeal candidiasis in RSUP Dr. Kariadi Semarang.

Methods : This was an observational descriptive study on HIV/AIDS patients with oropharyngeal candidiasis who were hospitalized in Internal Medicine Ward RSUP Dr. Kariadi Semarang during December 2010-May 2011. The diagnostic criteria of oropharyngeal candidiasis were obtained from microbiological identification (gram stained, culture, germ tube and fermentation).

Results : Fourty two HIV/AIDS patients with oropharyngeal candidiasis consist of 29 males (69\%), mostly between 30-39 years old, majority were labors and private workers (21.43\%), married (88.09\%), underweight (52.38\%), CD4 $<50$ cells/ $\mu$ l (78.57\%), and came from Semarang. Microbiologic cultures from 40 samples showed candida colonies of which $75 \%$ of them grew $>300$ candida colonies and were $55 \%$ non C. albicans, comprised of $15 \%$ C. stellatoidea, $15 \%$ C. tropicalis, $12.5 \%$ C. parapsilosis, $7.5 \%$ C. krusei, $2.5 \%$ C. glabrata, and $2.5 \%$ C. guilliemondia.

Conclusion : Most of the HIV/AIDS patients with orophayingeal candidiasis had CD4 $<50$ cells/ $\mu$ l, candida colonies found at the microbiological cultures, among $55 \%$ of which were non C. albicans.
\end{abstract}

Keywords: Oropharyngeal candidiais, HIV/AIDS 


\section{PENDAHULUAN}

Masalah HIV/AIDS adalah masalah besar yang mengancam Indonesia dan banyak negara di seluruh dunia. ${ }^{1}$ Epidemi HIV/AIDS di Indonesia paling cepat di Asia. ${ }^{3}$ Secara kumulatif kasus HIV/AIDS di Indonesia sampai Juni 2012, HIV: 86.762, AIDS:32.103.

Hasil penelitian di RS Dr. Cipto Mangunkusumo Jakarta menunjukkan bahwa infeksi oportunistik yang tersering adalah kandidiasis orofaringeal sebesar 80,8\%. ${ }^{7}$ Di RSUP Dr. Kariadi Semarang didapatkan pasien HIV/AIDS dengan infeksi oportunistik kandidiasis orofaringeal sebesar $79 \% .{ }^{10}$

Kandidiasis orofaringeal adalah infeksi oportunistik mukosa yang umumnya disebabkan oleh jamur Candida albicans, tetapi dapat disebabkan oleh spesies lain seperti Candida glabrata, Candida tropicalis, dan Candida krusei. ${ }^{11}$ Pada penelitian Egusa, dkk dilaporkan bahwa pasien HIV dengan kandidiasis orofaringeal memiliki resiko 2,5 kali lebih progresif menjadi AIDS daripada pasien HIV tanpa kandidiasis orofaringeal. ${ }^{12}$

Penelitian ini bertujuan untuk mengetahui karakteristik dan jenis kandida pada pasien HIV/AIDS dengan kandidiasis orofaringeal di RSUP Dr. Kariadi Semarang.

\section{METODE}

Penelitian ini adalah penelitian deskriptif observasional terhadap pasien HIV/AIDS yang dirawat di Bangsal Penyakit Dalam RSUP Dr. Kariadi Semarang pada Desember 2010-Mei 2011 menderita infeksi oportunistik berupa kandidiasis orofaringeal dengan kriteria diagnosis melalui identifikasi (pengecatan gram, kultur, germ tube dan fermentasi).

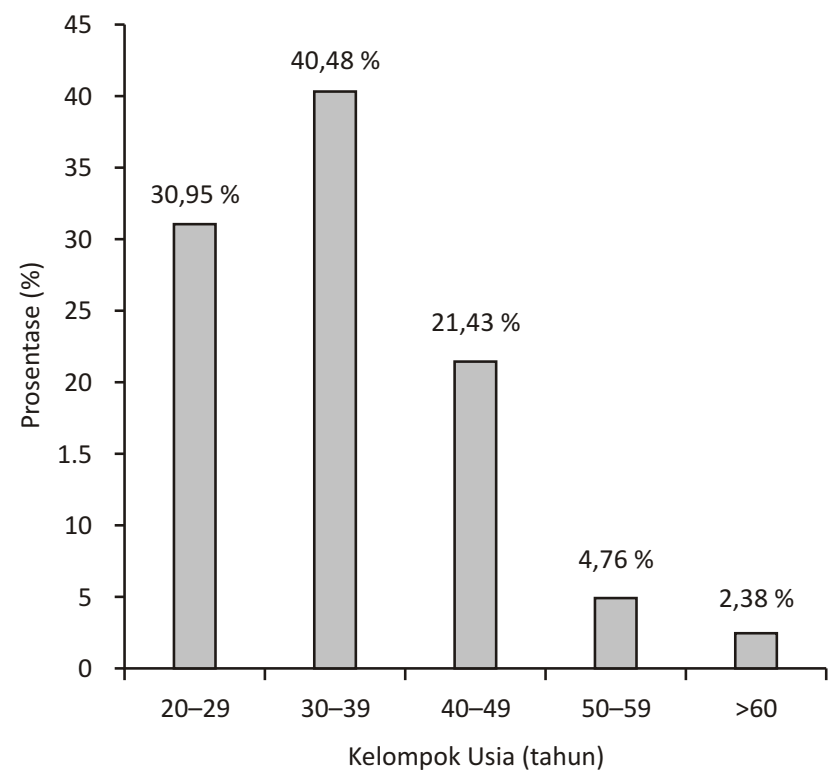

Gambar 1. Prosentase berdasarkan kelompok usia

\section{HASIL}

Hasil penelitian pada pasien HIV/AIDS dengan kandidiasis orofaringeal di RSUP Dr. Kariadi Semarang periode Desember 2010 - Mei 2011 didapatkan 42 pasien. Semua pasien HIV/AIDS yang dirawat pada periode tersebut dan mempunyai kandidiasis orofaringeal diikutkan dalam penelitian.

1. Jenis kelamin dan usia

Pasien laki-laki 29 orang (69\%), wanita 13 orang $(31 \%)$. Rentang usia terbanyak 30-39 tahun: 17 orang $(40,48 \%)$ (Gambar 1).

2. Pendidikan terakhir

Pendidikan terakhir terbanyak: sekolah dasar (SD): 13 orang $(30,95 \%)$.

3. Pekerjaan

Prosentase berdasarkan pekerjaan terbanyak: buruh dan pegawai swasta : 9 orang $(21,43 \%)$ (Gambar 2).

4. Status pernikahan

Status pernikahan sebagian besar sudah menikah : 37 orang $(88,09 \%)$.

5. Status gizi

Berdasarkan perhitungan indeks masa tubuh (IMT) : 22 pasien (52,38\%) status gizi di bawah normal/ underweight.

6. Kota tempat tinggal

Terbanyak berasal dariSemarang: 14 orang (Tabel5).

7. Pemeriksaan CD4.

41 pasien diperiksa CD4 dan 1 pasien tidak diperiksa $\mathrm{CD} 4$, prosentase tertinggi kadar $\mathrm{CD} 4<50 \mathrm{sel} / \mu 1$ : 33 orang $(78,57 \%)$. ( grafik 3 ).

8. Jumlah koloni kandida hasil kultur mikrobiologi Pemeriksaan kultur mikrobiologi menggunakan Sabouroud Dextrosa Agar (SDA) plate terhadap kandidiasis orofaringeal. Gambar 4 menunjukkan

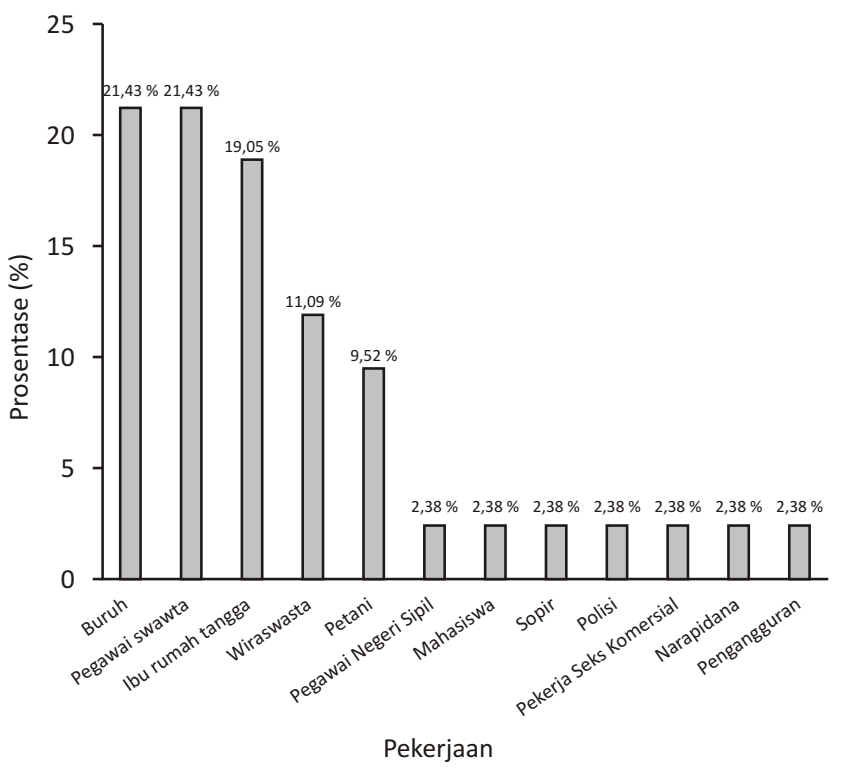

Gambar 2. Prosentase berdasarkan pekerjaan 


\begin{tabular}{lc|}
\hline Distribusi kota tempat tinggal pasien \\
\hline Kota Tempat Tinggal & $\begin{array}{c}\text { Jumlah pasien } \\
\text { HIV/AIDS }\end{array}$ \\
\hline Semarang & 14 \\
Demak & 5 \\
Kudus & 5 \\
Blora & 4 \\
Grobogan & 4 \\
Pekalongan & 3 \\
Ambarawa & 1 \\
Pati & 1 \\
Pemalang & 1 \\
Purworejo & 1 \\
Rembang & 1 \\
Yogyakarta & 1 \\
Banjarmasin & 1 \\
\hline
\end{tabular}

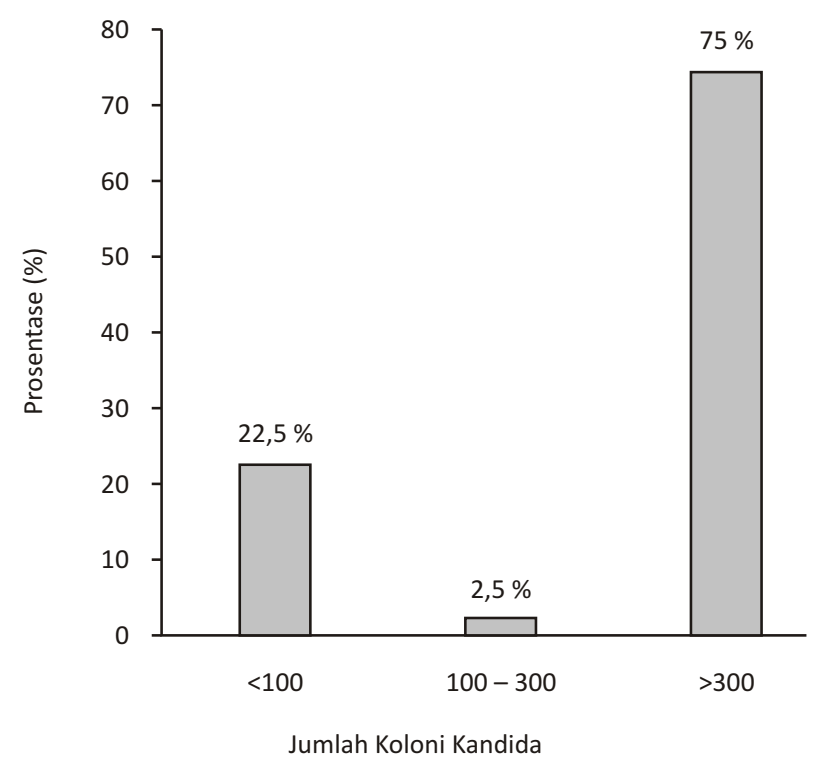

Gambar 4. Jumlah koloni kandida hasil kultur mikrobiologi

dari 40 sampel yang tumbuh koloni kandida dan 2 sampel tidak tumbuh koloni kandida. 30 sampel (75\%) tumbuh $>300$ koloni kandida.

9. Jenis spesies Kandida hasil pemeriksaan mikrobiologi

Didapatkan: 7 spesies kandida. C. albicans sebanyak 18 isolat (45\%) dan non C. albicans sebanyak 22 isolat $(55 \%)$ yang terdiri dari C. stellatoidea, C. tropicalis, C. parapsilosis, C.krusei, C. glabrata, C. guilliermondia (grafik 5).

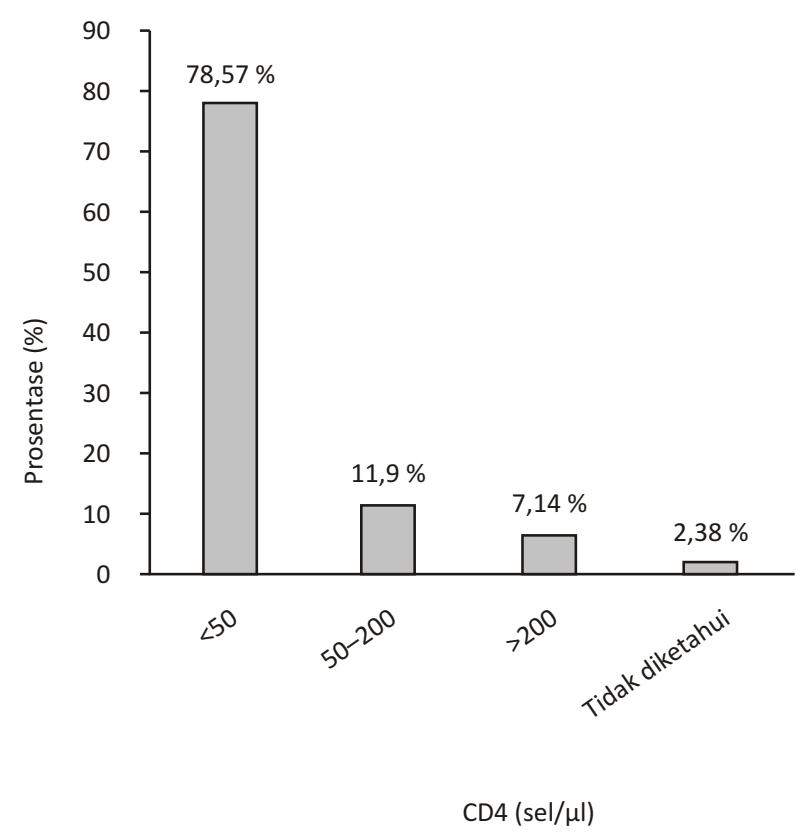

Gambar 3. Prosentase berdasarkan jumlah CD4

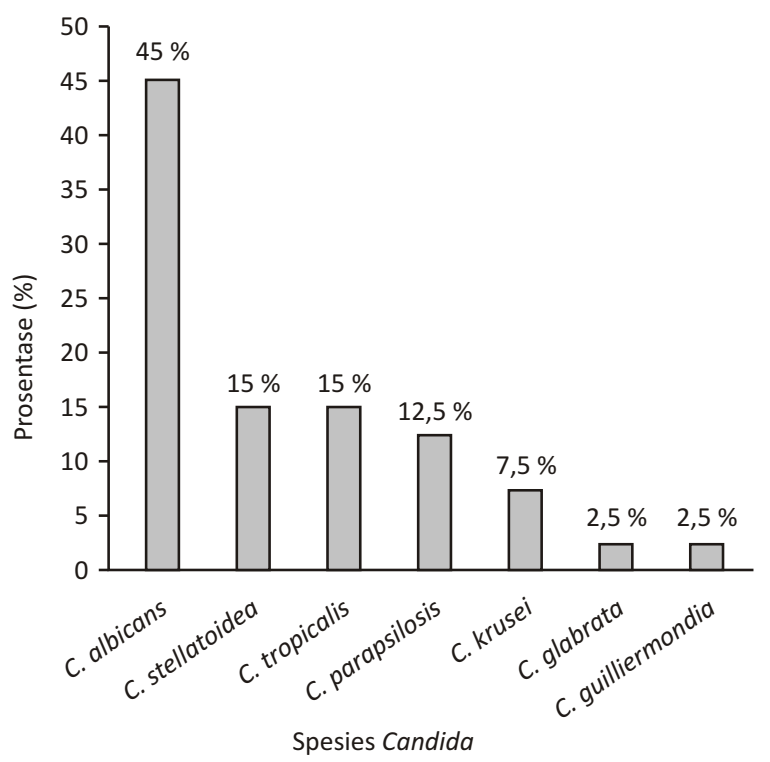

Gambar 5. Spesies kandida

\section{DISKUSI}

Selama periode Desember 2010 -Mei 2011 didapatkan 42 pasien HIV / AIDS dengan kandidiasis orofaringeal: 29 pasien laki-laki (69\%) dan 13 wanita (31\%). Sebagian besar berusia $30-39$ tahun (40,48\%). Hal ini sama dengan Tarini di Pokdiksus HIV/AIDS RSCM Jakarta namun usia terbanyak usia 20 - 29 tahun. $^{13}$

Pendidikan terakhir terbanyak Sekolah Dasar (SD): $30,95 \%$. Hal ini menyebabkan pengetahuan yang 
rendah mengenai HIV/AIDS sehingga dimungkinkan lebih rentan menderita HIV/ AIDS akibat ketidaktahuan mengenai faktor resiko penularan HIV. ${ }^{15}$

Distribusi pekerjaan terbanyak pegawai swasta $(21,43 \%)$ dan buruh $(21,43 \%)$. Ibu rumah tangga menempati urutan kedua terbanyak $(19,05 \%)$. Hal ini berbeda dengan Tarini di mana subjek yang paling banyak tidak bekerja/ pengangguran. ${ }^{13}$

Status pernikahan : 37 pasien $(88,09 \%)$ sudah menikah, yang belum menikah : 5 pasien $(11,09 \%)$.

Status gizi, menggunakan perhitungan indeks masa tubuh (IMT) didapatkan : 22 pasien $(52,38 \%)$ di bawah normal/underweight. HIV dan nutrisi sangat erat kaitannya. Infeksi HIV dapat menyebabkan kekurangan gizi, sementara pola makan yang buruk dapat mempercepat progresifitas infeksi HIV. Salah satu penyebab penurunan berat badan pada penderita HIV karena meningkatnya pengeluaran energi. Batterham menyatakan pasien HIV cenderung membakar kalori sekitar 10\% lebih banyak saat istirahat dibandingkan dengan orang yang tidak terinfeksi HIV.${ }^{16}$ Enwonwu di Nigeria menyebutkan bahwa Infeksi HIV mempengaruhi status gizi akibat berkurangnya asupan makanan yang disebabkan oleh hilangnya nafsu makan, efek samping obat, dan infeksi oportunistik seperti diare kronik, kandidiasis orofaringeal dan limfadenopati generalisata. ${ }^{17}$

Berdasarkan distribusi daerah asal pasien: sebagian besar berasal dari Semarang dan kabupaten sekitarnya yaitu 14 pasien $(33,33 \%)$, diikuti Kabupaten Demak dan Kudus masing-masing 5 pasien (11,90\%).

Sebanyak 41 dari 42 subjek $(97,62 \%)$ diperiksa jumlah CD4. Ketiadaan pemerikasaan jumlah CD4 pada 1 pasien $(2,38 \%)$ karena pasien meninggal sebelum diperiksa jumlah CD4-nya. Sebagian besar CD4 $<200 \mathrm{sel} / \mu \mathrm{l}$, : 33 pasien $(78,57 \%)$ CD4 $<50 \mathrm{sel} / \mu \mathrm{l}$. Hal ini sesuai dengan penelitian Tarini.13 Penelitian Omardi Tanzania, menunjukkan $79,52 \%$ pasien HIV/AIDS dengan kandidiasis orofaringeal, mempunyai jumlah CD4 $<200 \mathrm{sel} / \mu \mathrm{l} .{ }^{18}$ Hal ini menunjukkan bahwa ada hubungan jumlah CD4 terhadap terjadinya infeksi oportunistik kandidiasis orofaringeal. Semakin rendah jumlah CD4, maka peluang untuk terjadinya infeksi oportunistik menjadi lebih besar. ${ }^{1,19}$

Sebanyak 40 sampel menunjukkan adanya pertumbuhan koloni kandida setelah dikultur di media Sabouroud Dextrosa Agar (SDA) plate, dimana 30 sampel $(75 \%)$ diantaranya tumbuh $>300$ koloni kandida. Kandida merupakan flora normal di dalam mulut manusia. Kandida dapat menjadi dominan dan menyebabkan infeksi yaitu kandidiasis. Hal ini terjadi terutama pada keadaan imunokompromise. ${ }^{19}$

Hasil pemeriksaan mikrobiologi terhadap 40 sampel swab orofaringeal menggunakan germ tube dan fermentasi didapatkan 7 spesies kandida meliputi C. albicans sebanyak 18 isolat (45\%) dan non C. albicans sebanyak 22 isolat (55\%) yang terdiri dari 6 isolat C. stellatoidea (15\%), 6 isolat C. tropicalis $(15 \%), 5$ isolat C. parapsilosis $(12,5 \%), 3$ isolat C. krusei $(7,5 \%)$, 1 isolat C. glabrata (2,5\%), 1 isolat C. guilliermondia (2,5\%).

Hasil ini sesuai penelitian Ningsih di RSUD Dr. Soetomo Surabaya dimana jumlah non C. albicans $(64,71 \%)$ lebih banyak daripada C. albicans (35,29\%). Ada 5 spesies yaitu 12 isolat merupakan C. albicans (35,29\%) dan 22 isolat merupakan non C. albicans yang terdiri dari 10 isolat C. tropicalis $(29,41 \%), 5$ isolat C. dubliniensis $(14,71 \%), 5$ isolat C. glabrata $(14,71 \%)$ dan 2 isolat C. guilliermondia $(5,88 \%){ }^{20}$

Berbeda dengan penelitian Tarini, penelitian di RSCM Jakarta mendapatkan jumlah C. albicans lebih banyak daripada non C. albicans. C. albicans : 96\% sedangkan non C. albicans : $4 \%{ }^{13}$

Penelitian di RSUP Dr. Kariadi Semarang mendapatkan hasil penelitian yang lebih variatif mengenai jenis kandida dibandingkan dengan penelitian Ningsih di RSUD Dr. Soetomo Surabaya dan penelitian Tarini di RSCM Jakarta.

Kelemahan penelitian ini terdapat pada pengambilan sampel. Pengambilan sampel hanya dapat diambil di bagian arcus palatoglosus dan bagian dorsal lidah yang sedekat mungkin dengan orofaring. Hal ini terjadi karena sulitnya mengambil swab orofaring pada pasien sadar maupun yang mengalami penurunan kesadaran. Pada pasien yang sadar terdapat reflek muntah sedangkan pada pasien yang mengalami penurunan kesadaran sulit berkomunikasi dan kondisi pasien tersebut tidak memungkinkan untuk membuka mulut dengan lebar dan menjulurkan lidah sebagaimana mestinya agar dapat diambil swab orofaringnya.

\section{SIMPULAN}

Karakteristik pasien HIV/AIDS dengan kandidiasis orofaringeal : presentase tertinggi jenis kelamin laki-laki $(69 \%)$, rentang usia $30-39$ tahun $(40,48 \%)$, tingkat pendidikan terakhir SD (30,95\%), pekerjaan buruh $(21,43 \%)$ dan pegawai swasta $(21,43 \%)$, berstatus menikah $(88,9 \%)$, status gizi di bawah normal/underweight (52,38\%), berasal dari Semarang (72,2\%), jumlah CD4 $<50 \mathrm{sel} / \mu \mathrm{l}(78,57 \%)$.

Pemeriksaan kultur mikrobiologi pada swab orofaring 42 pasien didapatkan hasil 40 sampel yang tumbuh koloni kandida dan 2 sampel tidak tumbuh koloni kandida, dimana pada 30 sampel (75\%) tumbuh $>300$ koloni kandida.

Penelitian di RSUP Dr. Kariadi Semarang mendapatkan hasil penelitian yang lebih variatif mengenai jenis kandida. Hasil pemeriksaan mikrobiologi terhadap 40 sampel swab orofaringeal didapatkan 7 spesies kandida meliputi C. albicans sebanyak 18 isolat $(45 \%)$ dan non C. albicans sebanyak 22 isolat $(55 \%)$ yang terdiri dari 6 isolat C. stellatoidea (15\%), 6 isolat C. tropicalis 
$(15 \%), 5$ isolat C. parapsilosis $(12,5 \%), 3$ isolat C. krusei $(7,5 \%), 1$ isolat C. glabrata $(2,5 \%), 1$ isolat C. guilliermondia $(2,5 \%)$.

Perlu dilakukan penelitian lebih lanjut mengenai karakteristik pasien HIV/AIDS dengan kandidiasis orofaringeal dengan waktu yang lebih lama, jumlah pasien yang lebih banyak dan dilakukan tes sensitivitas antifungi untuk mengetahui antifungi yang paling baik untuk pengobatan kandidiasis orofaringeal pada pasien HIV/AIDS. Swab orofaring sebaiknya diambil tepat pada bagian orofaring pasien.

\section{DAFTAR PUSTAKA}

1. Djoerban Z, Djauzi S. HIV/AIDS di Indonesia. In: Sudoyo A, Setiyohadi B, Alwi I, Setiati S, editors. Buku Ajar Ilmu Penyakit Dalam IV ed. Jakarta: Pusat Penerbitan IPD FKUI; 2006. p. 1803-8.

2. WHO. UNAIDS Report on the global AIDS Epidemic 2010.2010

3. Indonesia NACRo. Republic of Indonesia Country Report on the Follow up to the Declaration of Commitment On HIV/ AIDS (UNGASS) Reporting Period 2008/2009. 2009.

4. Kementerian Kesehatan Republik Indonesia. Laporan Triwulan Ketiga 2012 Kasus HIV- AIDS. 2012.

5. KPA. Epidemi HIV/ AIDS di Jawa Tengah. 2010.

6. CDC. Opportunistic infection2010.

7. Djoerban Z, Djauzi S. Penatalaksanaan Infeksi HIV di Pelayanan Kesehatan Dasar. II ed. Jakarta: Pusat Penerbitan FKUI; 2003.

8. Harahap EMR. Gambaran infeksi oportunistik pada penderita HIV di RSUP H. Adam Malik Medan. 2010.

9. Vazquez JA. Optimal management of oropharyngeal and esophageal candidiasis in patients living with HIV infection. 2010;2010:2:89-101.

10. Sofro MAU, Gasem MH, Riyanto B, Hadisaputro S. Hubungan antara hitung CD4 dengan mortalitas pada pasien HIV-AIDS di RSUP Dr. Kariadi Semarang. 2006.
11. Ellepola ANB, Samaranayake LP. Antimycotic agents in oral candidosis: an overview: 1. Clinical variant. 2000;27(3):111-2, 46.

12. Sharma G, Pai KM, Suhas S, Ramapuram JT, Doshi D, N A. Oral manifestations in HIV/AIDS infected patients from India. 2006;12:537-42.

13. Tarini NMA, Mardiastuti, Ibrahim F, Yasmon A, Djauzi S. Karakteristik pasien HIV/AIDS dengan kandidiasis orofaringeal di Pokdisus HIV/AIDS Rumah Sakit Cipto Mangunkusumo Jakarta. 2008.

14. Effendy N, Prawitasari JE, Hastjarjo TD, Nasronudin. Pengaruh Psikoterapi Transpersonal terhadap Kualitas Hidup Pasien HIV dan AIDS. Anima,Indonesian Psycological Journal. 2008;24(1):1-16.

15. Oktarina, Hanafi F, Budisuari MA. Hubungan atara karakteristik responden, keadaan wilayah dengan pengetahuan, sikap terhadap HIV/AIDS pada masyarakat Indonesia. 2007.

16. Batterham MJ. Investigating heterogeneity in studies of resting energy expenditure in persons with HIV/AIDS: a metaanalysis. American journal of clinical nutrition. 2005;81(3).

17. Enwonwu CO. Complex interaction between malnutrition, infection and immunity: relevance to HIV/AIDS infection. Nigerian Journal of Clinical \& Biomedical Research. 2006;1(1).

18. The United republic of Tanzania MoH. National AIDS Control Programme (NACP): National Guidelines for the clinical management of HIV and AIDS. 2 ed2005.

19. Brooks GF, Butell JS, Morse SA. AIDS dan Lentivirus. Mikrobiologi kedokteran Jawetz, Melnick, \& Adelberg. 23 ed. Jakarta: EGC; 2007.p. 617-32.

20. Ningsih W, Hasrulliana, Suyoso, Sunarso, Prakoeswa, Sigit CR. manifestasi klinis dan identifikasi spesies penyebab kandidiasis oral pada pasien hiv/aids rsud dr. soetomo surabaya. BERKALA Ilmu Kesehatan Kulit dan Kelamin. 2010;22(1):11-6. 